\title{
MIR1-2 wt Allele
}

National Cancer Institute

\section{Source}

National Cancer Institute. MIR1-2 wt Allele. NCI Thesaurus. Code C81862.

The human MIR1-2 wild-type allele is located in the vicinity of $18 q 11.2$ and is approximately 84 bases in length. This allele, which encodes MIR1-2 pre-miRNA, plays a role in the regulation of gene expression. Alteration in the expression of this gene is associated with cardiomyopathy. 